\title{
ETHICAL VALUES OF DEMOCRACY ACCORDING TO JOHN DEWEY
}

\author{
Carolus Borromeus Mulyatno | Department of Philosophy \\ Faculty of Theology \\ Sanata Dharma Catholic University \\ Yogyakarta, Indonesia
}

\begin{abstract}
:
John Dewey never publishes a special work on theory of democracy. Nevertheless, his concern with democracy is undoubted. What is his main thought of democracy? This article is a textual analysis of the idea of democracy spread on his various works. As an experimentalist, his thought on democracy is to respond social problems. He views that two fundamental problems of democracy in his era are a tendency of reducing the meaning of democracy and social movements using violence in the name of political democracy. Dewey does not only look for the solution of the problems of democracy, but also put democracy in living process. The idea of liberty, equality and fraternity, as the democratic trinity, is ethical ideal of humanity. As an ethical idea, it should inspire each person in developing society for a better life. For this reason, he underlines the important of actualizing democracy through education.
\end{abstract}

Keywords:

democracy - ethic - values - education - responsibility - living process • better life

\section{Introduction}

John Dewey's life can be characterized as "an age of radical political upheavals and cultural dislocation." "1 He experienced various wars and developing industrialisation. In his era, there were many social and educational movements for responding social problems as consequences of wars and industrialization. 
During his public career, Dewey was a witness of totalitarian and authoritarian movements. Fascism founded by Benito Mussolini in 1919, Nazi Germany under Hitler, Soviet Union under Stalin and then Communism in China were usually regarded as prototypes of the totalitarian system. The success of Nazism brought wide political and social effects. The victory of Nazism in 1933 signified well over of half the German electorate voted for an antidemocratic, totalitarian, imperialistic program. Racism and totalitarianism in any form are a symbol of contra democracy. As a philosopher who developed experimentalism, Dewey tried to find a contribution of philosophy for achieving a better human life. He worked hard to develop democracy through academic and social activities.

In Dewey's view, democracy is principally moral idea that is a spirit of a process of living. Democracy should be actualised endlessly in daily life. Each human individual is free to actualise its self-realisation. Liberty is a spirit of he every human individual. Each individual has a right to equal opportunity with every other person to develop whatever endowment he has. Fraternity is an ethical value, which every human individual is able to actualise his capacities only in actively cooperative relationship with other. Political and social democracy presenting in a real association of life will be effectively sustained if its values of ideal humanity becomes an animating force of life.

Democracy is a symbol of the highest ethical idea. It is a valuable ideal that must be achieved by the educative process. The process and the goal of education are one and the same thing that is to achieve democracy as the full development of individuals as social beings. Hence education is inevitably a process of actualization of democracy.

To discover the thought of John Dewey on ethical values of democracy, this research elaborates textual analysis. ${ }^{2}$ It is important to read first the texts as presented by Dewey for examining systematically his main arguments related to ethical values of democracy. Before analyzing his writings, it is presented social context that urged Dewey to develop democracy. This research is "to analyze texts in order to clarify their contribution to process of meaning-making." ${ }^{3}$ This article is aimed to extend the meaning-making of Dewey's thought on the ethical values of democracy. 


\section{Social Context}

John Dewey describes the social context in his era as a crisis in which democracy "was won in a more or less external and accidental manner." He underlines two serious problems of democracy. They are a reduction of the sense of democracy and political movements using violence.

Dewey states that there is a tendency in which democracy is reduced as a form of government. For him, it is a serious mistake. ${ }^{5}$ To view democracy simply as a form of government is an impoverishment of the sense of democracy. Democracy is "primarily a mode of associated living, of conjoint communicated experience." "From this perspective, democracy as a regulation and form of government is a means of developing quality of society. For this reason, when many social activists express the important progressive reform intended to democracy government" and struggled to a broad of movement for greater public participation in the political process, Dewey focuses on the development of democracy as an ethical idea. He emphases that democracy is wider than political discourse. Democracy should be a spirit of individuals in all relations of life.

Other form of reducing democracy is "to identify democracy with economic individualism as the essence of free action." " As a consequence of this sense is to understand the role of government as an instrument of supporting individuals' economical welfare in which men derive a profit from one another. Dewey criticizes the position of some thinkers that emphasizes the necessity of democratic government only as an instrument for protecting and developing the economical interest of individuality. ${ }^{8}$

For responding the erosion of the sense of democracy, Dewey reaffirms Thomas Jefferson's standpoint, one of the founding fathers of American democracy, who expresses that "the claims of democracy were inherently one with the demands of a just and equal morality." He asserts: "We now have to re-create by deliberate and determined endeavour the kind of democracy which in its origin one hundred and fifty years ago was largely the product of a fortune combination of men and circumstances." ${ }^{10} \mathrm{He}$ underlines "the necessity of free press, general schooling and local neighborhood groups carrying on, through intimate meeting and discussion, the management of their own affairs, if political democracy was to be made secure."11 For Dewey, press should be a means 
of public education. In reality, it often becomes a tool of capitalism's interest. For getting many customers, it reports sensational news such as "ordinary reports of murders, love nests, etc." that appeal to those who like things raw. ${ }^{12}$ Consequently, "the habit of using judgment is weakened by the habit of depending on external stimuli." "I It is a cultural problem. For that reason, John Dewey highlights that "the problem of creation of genuine democracy cannot be successfully dealt with in theory or in practice save as we create intellectual and moral integration out of present disordered conditions." ${ }^{\prime 14}$

Within the above-mentioned social context, John Dewey develops his concept on democracy as an ethical idea. Moreover, he envisions that democracy becomes a way of life and is not simply a form of government. ${ }^{15}$

\section{Ethical Aspect of Democracy}

John Dewey holds that the most important aspect of democracy is ethical. ${ }^{16}$ This is "an ethical conception, and upon its ethical significance is based its significance as governmental. Democracy is a form of government only because it is a form of moral and spiritual association.”17 Underlining democracy as an ethical idea is his response to the political movements in his era where democracy is often reduced to a form of government for securing the economic welfare of the people.

The ethical aspect of democracy is uncovered in the meaning of three pillars of democracy, that are liberty, equality and fraternity. They are fundamental values of democracy. They have an equal sense with the opening words of the Declaration of Independence: "These truths are self evident: that all men are created equal; that they are endowed by their Creator with inherent and unalienable rights; that among these are life, liberty and the pursuit of happiness." ${ }^{\text {C18 }}$

Liberty is not merely the self-assertion of an individual that is a loss of reverence and order. ${ }^{19}$ Dewey asserts that liberty is "an ethical idea that personality is the supreme and only law, that every man is an absolute end in himself." ${ }^{\prime 20}$ It seems that Dewey's idea of personality as the supreme and the only law is influenced by Emanuel Kant's thought that he received from H.A.P. Torrey during his study. ${ }^{21}$ Furthermore, he adds: "The democratic ideal includes liberty because democracy without initiation from within, without an ideal chosen from within and freely followed by initiation from within, is nothing." 22 
Dewey's equality has nothing to do with numerical equality and the equal division of all things from virtue to wealth, but it is an ethical conception. As he explains:

"Equality is as universal as humanity; it is indifferent to all distinction which divide men from men. Wherever you have a man, there you have personality, and there is no trace by which one personality may be distinguished from another so as to be set above or below. It means that in every individual there lives an infinite and universal possibility... The true meaning of equality is synonymous with the definition of democracy given by James Russell Lowell. It is the form of society in which every man has a chance and knows that he has it - and we may add, a chance to which no possible limits can be put, a chance which is truly infinite, the chance to become a person. Equality, in short, is the ideal of humanity; and ideal in the consciousness of which democracy lives and moves." 23

Equality is an ethical idea, which consists of a conviction that "democracy has always professed belief in the potentialities of every human being, and all the need for providing conditions that will enable these potentialities to come realization." ${ }^{24}$ It indicates the quality and uniqueness of every individual.

Like liberty and equality, fraternity is also an ethical idea. Fraternity means "the will to work together; it is the essence of cooperation." ${ }^{25}$ Here he wants to reaffirm that democracy not only includes the liberties of free speech, publication and assembly, but also it involves the effort of active cooperation. The idea of fraternity as active cooperation reaffirms his reflection on the social dimension of individuals. He asserts that every individual which is "specific and unique can be exhibited and become forceful or actual only in relationship with other." $26 \mathrm{He}$ affirms that democratic society has the ethical end or final aim of developing human nature to bring a person into complete harmony with the universe in the community. ${ }^{27}$ The development of the individual in harmony with all other in the state is not only the end of politic but also ethics that its fundamental concern is to develop morality. Therefore, democracy is a process of promoting morality.

Underlining democracy as a moral association of individual in society, Dewey states: 


\begin{abstract}
"A social democracy signifies, most obviously, a state of social life where there is a wide and varied distribution of opportunities; where there is social nobility or scope for change of position and station; where there is free circulation of experiences and ideas, making for a wide recognition of common interests and purposes, and where utility of social and political organization to its members is so obvious as to enlist their warm and constant support in its behalf." 28
\end{abstract}

The social aspect of democracy is characterized in qualities like insistence upon widespread opportunity, free exchange of ideas and experience, and extensive realization of the purposes that bind people together. These qualities "are intellectual and emotional traits." 29 For this reason, he identifies a social democracy as a moral democracy.

Dewey shows that a fundamental aspect of democracyis communitarian. Liberty, equality, and fraternity, which together form the democratic triad, are ethical ideals of humanity that must animate any form of society. ${ }^{30} \mathrm{He}$ emphasizes that democracy has its being in the community of truth that develops brotherhood. ${ }^{31}$ Furthermore, he affirms that through communal action, democracy "becomes a living, present thing, having its ordinary and natural sense." ${ }^{32}$

Moral or social democracy refers to "a mode of associated living, of conjoint communicated experience." $33 \mathrm{He}$ also asserts that "two traits are precisely what characterize the democratically constituted society." 34 The shared concern and interests between individuals, which have a diversity of capacities, is an important trait of democratic society. There is numerous and more varied points of shared interest. Furthermore, there is also the greater reliance upon the recognition of mutual interests as a factor in social control. Free interaction between social groups, change in social habits, and continuous readjustment through meeting for transformation are also character of democracy.

Democracy is concerned, above all, with "associated individuals in which each by intercourse with others somehow makes the life of each more distinctive." ${ }^{35}$ In relationship with others, individuals come together in joint intercourse and action, which is increased and confirmed by being shared. Every individual is a member of many groups. There are as many groups as "there are goods which are enhanced by being mutually communicated and participated in." 36 Moreover, "the increasing acknowledgment that goods exist and endure only through being communicated and that 
association is the means of conjoint sharing lies back of the modern sense of humanity and democracy." ${ }^{37}$ In Dewey's perspective, "democracy is not an alternative to other principles of associated life. It is the idea of community life itself." 38

Democracy, as the idea of community in its full measure, has not found its full representation. This does not mean that the ideal of community is only an empty dream. He affirms that "the ideal of a community presents, however, actual phases of associated life as they are freed from restrictive and disturbing elements, and are contemplated as having attained their limit of development." 39 Only when it starts from a community as a fact, can the idea of democracy be reached. Democracy is present in a real community marked by shared activities and values, an effort to sustain a good shared by all and an opened attitude to transform the community. Therefore, "the clear consciousness of a communal life, in all its implications, constitutes the idea of democracy." 40

For the above arguments, in Dewey's view, if the ethical idea of humanity, as liberty, equality and fraternity, is separated from communal life, they become mathematical ideas without spirit. He states: "Fraternity, liberty and equality isolated from communal life are hopeless abstractions." Therefore, Dewey asserts:
"Fraternity is another name for consciously appreciated goods which accrue from an association in which all share, and which give direction to the conduct of each. Liberty is that secure release and fulfilment of personal potentialities which take place only in rich and manifold association with others: the power to be an individualized self making a distinctive contribution and enjoying in its own way the fruits of association. Equality donates the unhampered share which each individual member of the community has in consequences of associated action. It is equitable because it is measured only by need and capacity to utilize, not by extraneous factors which deprive one in order that another may take and have." 42

Fraternity, liberty and equality are the united spirits in connection with the communal experience which indicates an inseparable organic relation between individuals and society. Accordingly, Dewey explains that "communal life is moral, that is emotionally, intellectually, consciously sustained." 43

Recalling the idea of Thomas Jefferson on the ethical aspect of democracy ${ }^{44}$, Dewey underlines that democracy is moral: "in its 
foundations, its methods, its ends." ${ }^{45} \mathrm{He}$ emphasizes that "it is moral because [it is] based on faith in the ability of human nature to achieve freedom for individuals accompanied with respect and regard for other persons and with social stability built on cohesion instead of coercion." ${ }^{46}$ The foundation of moral democracy is "a faith in the capacity of human beings for intelligent judgment and action." 47

In addition, democracy is a spirit that forms personal character and determines desire and purpose in all the relations of life. ${ }^{48}$ He says that "the idea remains barren and empty save as it is incarnated in human relationship. To be realized it must affect all modes of human association, the family, the school, industry, religion." ${ }^{\prime 49}$ Furthermore, he asserts that "the next religious prophet who will have a permanent and real influence on man's lives will be the man who succeeds in pointing out the religious meaning of democracy, the ultimate religious value to be found in the normal flow of life itself." 50

In the last paragraph of The Ethics of Democracy, Dewey affirms that the idea of democracy, the ideas of liberty, equality, and fraternity, represent a society as the union of the spiritual and the secular aspect of life. ${ }^{51}$ Democracy is a spiritual fact. It is "not a mere piece of governmental machinery." 52 He affirms that "Christianity is revelation, and revelation means effective discovery, the actual asserting or guaranteeing to man of the truth of his life and the reality of the Universe. It is at this point that the significance of democracy appears." ${ }^{53}$ The idea of Christianity is to be identified with the ongoing process of revelation of truth that have to seek an expression in the social organism.

As the revelation of truth must continue as long as life has new meanings to unfold and has new action to propose, the democratic ideal must be actualised constantly in actions as a social aspect of Christianity. The democratic ideal, which is an expression of the Christian Ideal of a Kingdom of God on earth or an expression of the perfection of community life, must be presented in community life. Democracy has a spiritual meaning in relating to the meaning of freedom. For this idea, he argues:

"Democracy is freedom. If truth is at the bottom of things, freedom means giving this truth a chance to show itself, a chance to well up from the depths. Democracy, as freedom, means loosening of bonds, the wearing away of restrictions, the braking down of barriers, of middle 
walls, of partitions. Through this doing away with restriction, whatever truth, whatever reality there is in man's life is freed to express itself. Democracy is, as freedom, the freeing of truth." ${ }^{54}$

The idea of freedom constitutes two meanings. Firstly, freedom means loosening of bonds. Secondly, it means the freeing of each individual to express himself. Only the truth makes every individual free. Emphasizing a social nature of person, Dewey expresses that the freedom of truth, which is democracy, has its being in the community of truth as the realization of brotherhood. ${ }^{55}$ "It is in democracy, the community of ideas and interest through community of action, that the incarnation of God in man (man, that is to say, as organ of universal truth) becomes living, presenting, having its ordinary and natural sense." 56

John Dewey asserts that "the next religious prophet who will have a permanent and real influence on man's lives will be the man who succeeds in pointing out the religious meaning of democracy, the ultimate religious value to be found in the normal flow of life itself." ${ }^{57}$ The task for realizing democracy is enduring efforts to reveal the truth continuously.

\section{Actualizing Democracy through Education}

Ethical values of democracy are connected to humanity as a subject and aim of democracy. ${ }^{58}$ We live ethical values of democracy in doings and sufferings of our continuous living together in our community which we are a link. ${ }^{59}$ It is the responsibility of each member of our community in conserving, transmitting and expanding the values of democracy. The future generation after us may receive them more solid and secure. Then, they share them more generously than us.

In the social context of his era John Dewey worries about various forms of the repressions countering to cultural freedom that is a trait of democracy. As he expresses:

"As we listen to accounts of the repression of culture freedom in countries which have been swept by totalitarian terror, let us bear in mind that our chief problems are those within our culture. In the modern world, every country under some circumstances becomes fertile soil for seeds out of which grow fanatical conflict, intolerance, racial oppression. The attitude which prevails in some parts of the country towards Negroes, Catholics and Jews is spiritually akin to excesses that have made a shambles of democracy in other countries of the world." 60 
Dewey believes: "The conflict between the methods of freedom and those of totalitarianism is within our own institutions and attitudes." Thus, it is important "the application of democratic methods, in the task of making our own politics, industry, education - our culture generally - a servant and an evolving manifestation of democratic ideas." ${ }^{.2}$ He identifies democratic method with "persuasion through public discussion carried on not only in legislative but in the press, private conversions and public assemblies." ${ }^{63}$ The application of democratic method extensively is none other than a realization of democracy.

Considering the treat of totalitarianism to democracy, John Dewey emphasizes:

"Our first defense is to realize that democracy can be can be served only by the slow day by day adoption and contagious diffusion in every phase of our common life of methods that are identical with the ends to be reached. There is no substitute for intelligence and integrity in cultural life. Anything else is a betrayal of human freedom no matter in what guise it presents itself. An American democracy can serve the world only as it demonstrates in the conduct of its own life the efficacy of plural, partial, and experimental methods in securing and maintaining an ever-increasing release of the powers of human nature, in service of freedom which is cooperative and a cooperative which is voluntary." ${ }^{64}$

The effective application of democratic methods is none other than the end of democracy that to be reached in the certain time and that is demonstrated in the conduct of life. Nevertheless, democracy is a process, so it is important to apply the intelligence for criticizing methods used and for discovering the worthy realization of democracy. For democracy is as a cooperative experiment, it is important the role of "collective intelligence operating in cooperative action." ${ }^{65}$

To develop democracy continuously, Dewey highlights the important of applying democratic methods. Democratic methods are characterized by methods of consultation, persuasion, negotiation, cooperative intelligence, criticism and cultural freedom. As he expresses, "the task of democracy is forever that of creation of a freer and more human experience in which all share and to which all contribute." ${ }^{\circ 6}$ Thus, it is an imperative task to actualise democracy continuously.

The significant contribution of Dewey is his efforts to actualize this idea in practice. Through his Laboratory School in which he uses a democratic method, Dewey envisions that school becomes an educative 
community. School provides children with a rich sense of dialogue in a democratic community. This is important because "the older bases of community, in the extended family and the communal neighbourhood, were fast being destroyed by industrialization, urbanization, specialization of jobs, and increasing mobility." ${ }^{\prime 67}$

Dewey consistently defends his belief in education and democracy through both his works and activities. The role of education is inevitably for "the widening of the area of shared concerns, and the liberation of a greater diversity of personal capacities which characterize a democracy." 68 Education for all is the only means by which capacities and possibilities of each person should be made a reality.

Qualities like widespread opportunity for self-realization, free exchange of concerns, interests and experiences, and making wide recognition of common interest and purpose, "are intellectual and emotional traits." 69 These qualities do not develop spontaneously, but they are the fruits of education. As he points out:

"They have to be planted and nurtured. They are dependent upon education. It is no accident that all democracies have put a high estimate upon education; that schooling has been their first care and enduring charge. Only through education can equalities of opportunity be anything more than a phrase. Accidental inequalities of birth, wealth and learning are always tending to restrict the opportunities of some as compared with those of others. Only free and continued education can counteract those forces which are always at work to restore, in however changed a form, feudal oligarchy. Democracy has to be born anew in every generation, and education is its midway. Moreover, it is only education which can guarantee a widespread community of interest and aim." 70

Dewey believes that "the devotion of democracy to education is a familiar fact." 71 Developing education is inevitably a way to achieve democracy. He states that "a government resting upon popular suffrage cannot be successful unless those who elect and who obey their governors are educated." ${ }^{\prime 72}$ The role of education is very important in developing a voluntary disposition and interest of each person in a society. He adds: "Since democracies forbid, by their very nature, highly centralized governments working by coercion, they depend upon shared interest and experience for their unity, and upon personal appreciation of the value of institutions for stability and defence."73 
Dewey views a mutual relation between education and the democratic state. On one hand, "the realization of the new education destined to produce a new society was, after all, dependent upon the activities of states." 74 The implementation of progressive education needs the support of the state. On the other hand, "the movement for the democratic idea inevitably became a movement for publicly conducted and administrated schools." ${ }^{75}$ Qualities of a democratic state cannot be maintained and developed without the role of education. In other words, a democratic society is the means for educative process. Education is the effective instrument to actualize democracy. ${ }^{76}$ Thus, education has to be carried out as wide as a social process.

The educative process or the process of democratization is a task and responsibility of all individuals. It is expressed in the following affirmation: "Full education comes only when there is a responsible share on the part of each person, in proportion to capacity, in shaping the aims and policies of the social groups to which he belongs. This fact fixes the significance of democracy." "77 He underlines that "the realization of a form of social life in which the interests are mutually interpenetrating, and where progress, or readjustment, is an important consideration, makes a democratic community more interested than other communities have cause to be in deliberate and systematic education. ${ }^{, 78}$ For this reason he tries to develop and transform education in his epoch.

Dewey holds that the self-realization of the capacities of each person that is manifested in shared activities and interest is a real form of democracy. He views the "fundamental importance to the activities of individuals in determining the social conditions under which they live."79 Besides that, he also expresses:

"It has been shown in the last few years that democratic institutions are no guarantee for existence of democratic individuals. The alternative is that individuals who prize their own liberties and who prize the liberties of other individuals, individuals who are democratic in thought and action, are the sole final warrant for the existence and endurance of democratic institutions." 80

Consequently, education is an effective way in forming attitudes and in planting the qualities of democratic characteristics in individuals and societies. Education is a valuable instrument to embody the democratic values as a way of life of each individual, which is "the possession 
and continual use of certain attitudes, forming personal character and determining desire and purpose in all the relations of life." ${ }^{\prime 1}$

The crises in culture and education prompted Dewey to maintain a commitment to scientific intelligence in developing democratic attitude. Reconstruction in education is an inevitable vocation for social reconstruction. He underlines that "the realization of a form of social life in which the interests are mutually interpenetrating, and where progress, or readjustment, is an important consideration, makes a democratic community more interested than other communities have cause to be in deliberate and systematic education." 82

John Dewey affirms that "the devotion of democracy to education is a familiar fact." 83 There are two significance arguments. Firstly, from the governmental point of view, "a government resting upon popular suffrage cannot be successful unless those who elect and who obey their governors are educated." ${ }^{84} \mathrm{He}$ adds: "Since democracies forbid, by their very nature, highly centralized governments working by coercion, they depend upon shared interest and experience for their unity, and upon personal appreciation of the value of institutions for stability and defense." 85 Accordingly, the role of education is very important in forming a voluntary disposition and interest of individuals in a society. Secondly, considering that democracy is more than form of government, the role of education in extending the number of individuals who actively involves in sharing interest and experience for social progress is very significant.

\section{Conclusion}

To develop qualities moral and intellectual characterizing a democratic society, such qualities as a culture of freedom, recognition of individuals to participate in a common interest, inevitably needs education. Democratic society cannot be reality without voluntary initiative and voluntary cooperation of individuals who prize their own liberties and who prize the liberties of other individuals. In other words, democratic society cannot be reality without a democratic attitude and thought forming personal character and determining desire and purpose in all the relations of life. Education is an effective way for the actualisation of democracy. For education is a process of living, the endeavour for the actualisation of democracy must take place over the broad range of share activity of living. 
The intimate relation between democracy and education can be recognized primarily in the meaning of education. Dewey points out that "education, in its broadest sense, is the means of this social continuity of life." ${ }^{86}$ In other words, "education is a social function." ${ }^{87}$ Education has to concern with social problems. The main task of education is to transform human disposition, conduct and choice in concrete living. ${ }^{88}$

In his era, Dewey faces the money culture or "the practice of a pecuniary culture" 89 formed by the technological progress and industrialization as a challenge to education. For him, "the problem of the relation mechanical and industrial civilization to culture is the deepest and most urgent problem of our day." ${ }^{90}$ Considering this problems, he "refer to the schools in connection with this problem of American culture because they are the formal agencies for producing those mental attitudes, those modes of feeling and thinking, which are the essence of a distinctive culture."91 Furthermore, he underlines the important of education for actualizing democracy because education is a process of transforming individual and communal life continuously. The process of democratization is based on a belief of continuity. ${ }^{92}$

Dewey believes the role of education based on the capacities of human social intelligence for guarantying a better future life of society. ${ }^{93}$ In reality, no one is able to guarantee that each person will be interested to develop society. Nevertheless, it is reasonable that democracy is an educative process. Each person, families, press, and social institutions are main agent of democracy. Their chief responsibility is to develop and live atmosphere of dialogue and shared experience in cooperative work for actualizing democracy. ${ }^{94}$

\section{Bibliography}

\section{Books}

Bullet, Garry. The Politics of John Dewey. New York: Buffalo, 1983.

Campbell, James. Understanding John Dewey: Nature and Cooperative Intelligence.

Chicago: Open Court, 1995.

Dewey, John. Democracy and Education: an Introduction to the Philosophy of

Education. New York: The Free Press, 1966. . Reconstruction in Philosophy. Boston: Beacon Press, $1948^{2}$. 
. The Public and Its Problems. New York: Henry Holt, 1997. Individual, Old and New. New York: Minton, 1999. . Freedom and Culture. New York: G.P. Putnam's Sons, 1989.

Fairclough, Norman. Analyzing Discourse: Textual analysis for Social Research. London and New York: Routledge, 2005.

Fott, David. John Dewey: Amcerica's Philosopher of Democracy. New York: Roman and Littlefield Publishers, 1998.

Westbrook, Robert B. John Dewey and American Democracy. Ithaca: Cornell University Press, 1991.

\section{Articles}

Axtelle, Goerge E. \& Joe R. Burnett. "Dewey on Education and Schooling." Guide to the Works of John Dewey. ed. Jo Ann Boydston, Carbondale: Southern Illinois University Press, 1970, 257-305.

Dewey, John. "The Ethics of Democracy." The Political Writings. ed. Debra Morris and Ian Shapiro, Indianapolis: Hackett Publishing Company, 1993, 59-65.

. "Christianity and Democracy." The Early Works IV. ed. Jo Ann Boydston. Carbondale: Southern Illinois University Press, 1971, 3-10.

. "Creative Democracy - The Task Before Us." The Political Writings. ed. Debra Morris and Ian Shapiro. Indianapolis: Hackett Publishing Company, 1993, 240-245.

. "Philosophy and Democracy." The Political Writings. ed.

Debra Morris and Ian Shapiro. Indianapolis: Hackett Publishing Company, 1993, 38-47.

. "Democratic Ends Need Democratic Methods for Their

Realization.” The Political Writings. ed. Debra Morris and Ian Shapiro.

Indianapolis: Hackett Publishing Company, 1993, 205-206.

. "The Basic Values and Loyalty of Democracy." The Political

Writings. ed. Debra Morris and Ian Shapiro. Indianapolis: Hackett Publishing Company, 1993, 207-209.

. "I Believe." The Political Writings. ed. Debra Morris and Ian

Shapiro. Indianapolis: Hackett Publishing Company, 1993, 234-239. . "The Need of an Industrial Education in an Industrial Democracy." The Political Writings. ed. Debra Morris and Ian Shapiro. 
Indianapolis: Hackett Publishing Company, 1993, 121-124. . "The Democratic Faith and Education." The Later Works

XV. ed. Jo Ann Boydston. Carbondale: Southern Illinois University Press, 1989, 250-260. . "The Relation of Philosophy to Theology." The Early Works

$I V$. ed. Jo Ann Boydston. Carbondale: Southern Illinois University Press, 1971, 365-368.

. "Education, the Foundation for Social Organization." The

Later Works XI. ed. Jo Ann Boydston. Carbondale: Southern Illinois University Press, 1987, 226-235.

Mulyatno, C. B. " Philosophy as an Educative Process in John Dewey Pragmatism." Studia Philosophica et Theologica, Vol. 9, No.1, 2009, 6784. . "Demokrasi Sebagai Pola Hidup Menurut John Dewey." Diskursus, Vol.10. No.1, 2011, 1-29.

\section{Endnotes:}

1 Garry Bullert, The Politics of John Dewey (New York: Buffalo, 1983) 9.

2 Cf. Norman Fairclough, Analyzing Discourse: Textual analysis for Social Research (London and New York: Routledge, 2005) 10-12.

3 Ibid., 11.

4 James Campbell, Understanding John Dewey: nature and cooperative intelligence (Chicago: Open Court, 1995) 145.

5 Cf. John Dewey, "Creative Democracy - The Task Before Us," The Political Writings, ed. Debra Morris and Ian Shapiro (Indianapolis: Hackett Publishing Company, 1993) 241.

6 John Dewey, Democracy and Education: an Introduction to the Philosophy of Education (New York: The Free Press, 1916) 87.

7 John Dewey, "The Basic Values and Loyalty of Democracy," The Political Writings, ed. Debra Morris and Ian Shapiro (Indianapolis: Hackett Publishing Company, 1993) 207.

8 Cf. John Dewey, The Public and Its Problems (Ohio: Ohio University Press, 1997) 9395.

9 John Dewey, Freedom and Culture (New York: G.P. Putnam’s Sons, 1989) 100-101.

10 Dewey, "Creative Democracy," 241.

11 Dewey, Freedom and Culture, 37.

12 Ibid., 40.

13 Ibid. 
14 Ibid., 43.

15 Cf. Dewey, "Creative Democracy," 241.

16 Cf. C.B. Mulyatno, "Demokrasi Sebagai Pola Hidup Menurut John Dewey," Diskursus, Vol.10, No.1 (2011) 14-17.

17 John Dewey, "The Ethics of Democracy," The Political Writings, ed. Debra Morris and Ian Shapiro (Indianapolis: Hackett Publishing Company, 1993) 59.

18 Ibid.

19 Cf. ibid., 61.

20 Ibid., 62.

21 Cf. Robert Wesbrook, John Dewey and American Democracy (Ithaca: Cornell University Press, 1991) 6.

22 Dewey, "The Ethics of Democracy," 62.

23 Ibid., 63.

24 Dewey, "The Basic Values and Loyalties of Democracy," 208.

25 Ibid., 209.

26 John Dewey, "Philosophy and Democracy," The Political Writings, ed. Debra Morris and Ian Shapiro (Indianapolis: Hackett Publishing Company, 1993) 46.

27 Ibid., 59-61.

28 Cf. John Dewey, “The Need of an Industrial Education in an Industrial Democracy," The Political Writings, ed. Debra Morris and Ian Shapiro (Indianapolis: Hackett Publishing Company, 1993) 121-122.

29 Ibid.

30 Cf. Dewey, "The Ethics of Democracy," 65.

31 Cf. John Dewey, "Christianity and Democracy," The Early Works IV, ed. Jo Ann Boydston (Carbondale: Southern Illinois University Press, 1971) 9.

32 Ibid.

33 Dewey, Democracy and Education, 87.

34 Ibid., 86.

35 Ibid., 47.

36 John Dewey, Reconstruction in Philosophy (Boston: Beacon Press, 1948) 205.

37 Ibid., 206.

38 John Dewey, The Public and Its Problems, 148.

39 Ibid.,149.

40 Ibid.

41 Ibid.

42 Ibid., 150.

43 Ibid., p. 151.

44 Dewey calls Thomas Jefferson as a universal man who has a deep interest in education and democracy. In 1940 he dedicates a book entitled The Living Thought of Thomas Jefferson to note some interests and principal thoughts of Thomas Jefferson.

45 Dewey, Freedom and Culture, 119.

46 Ibid., 4.

47 Dewey, "Creative Democracy," 242. 
48

49 Dewey, The Public and Its Problems, 143.

50 John Dewey “The Relation of Philosophy to Theology," The Early Works IV, ed. Jo Ann Boydston (Carbondale: Southern Illinois University Press, 1971) 367.

51 Dewey, "The Ethics of Democracy," 65.

52 Dewey, "Christianity and Democracy," 8.

53 Ibid., 6-7.

54 Ibid.

55 Cf. Ibid., 9.

56 Ibid.

57 Dewey, "The Relation of Philosophy to Theology," 367.

58 Cf. Mulyatno, "Demokrasi Sebagai Pola Hidup Menurut John Dewey," 14.

59 Cf. CB. Mulyatno, "Philosophy as an Educative Process in John Dewey Pragmatism," Studia Philosophica et Theologica, Vol. 9, No.1 (2009) 80.

60 Dewey, "Democratic Ends," 205.

61 Ibid.

62 Dewey, Freedom and Culture, 133.

63 Ibid., 99.

64 Dewey, "Democratic Ends," 206.

65 Ibid.

66 Dewey, "Creative Democracy," 245.

67 George E. Axtelle \& Joe R. Burnett, "Dewey on Education and Schooling," Guide to the Works of John Dewey, ed. Jo Ann Boydston (Carbondale: Southern Illinois University Press, 1970) 269-270.

68 Ibid.

69 Dewey, "The Need of an Industrial Education," 122.

70 Ibid.

71 Dewey, Democracy and Education, 87.

72 Ibid.

73 Dewey, "The Need of an Industrial Education," 122.

74 Dewey, Democracy and Education, 93.

75 Ibid.

76 Cf. John Dewey, "Education, the Foundation for Social Organization," The Later Works XI, ed. Jo Ann Boydston (Carbondale: Southern Illinois University Press, 1987) 230.

77 Dewey Reconstruction in Philosophy, 209.

78 Dewey, Democracy and Education, 87.

79 John Dewey, "I Believe," The Political Writings, ed. Debra Morris and Ian Shapiro (Indianapolis: Hackett Publishing Company, 1993) 234.

80 Ibid., 234-235.

81 Dewey, "Creative Democracy," 241.

82 Dewey, Democracy and Education, 87. 
83 Ibid.

84 Ibid.

85 Dewey, "The Need of an Industrial Education," 122.

86 Dewey, Democracy and Education, 2.

87 Ibid., 81.

88 Cf. Mulyatno, " Philosophy as an Educative Process in John Dewey Pragmatism," 80.

89 John Dewey, Individualism, Old and New (New York: Prometheus Books, 1999) 9.

90 Ibid., 61.

91 Ibid.

92 David Fott, John Dewey: Amcerica's Philosopher of Democracy (New York: Roman and Littlefield Publishers, 1998) 85.

93 Cf. Mulyatno, " Philosophy as an Educative Process in John Dewey Pragmatism," 81.

94 Cf. Mulyatno, "Demokrasi Sebagai Pola Hidup Menurut John Dewey," 28. 